\title{
Supply Chain Management Pabrik Roti ABC Dengan Metode Weighted Moving Average (WMA)
}

\author{
Herlina $^{1}$, Yohansen ${ }^{2}$, Fransiska Prihatini Sihotang ${ }^{3}$ \\ ${ }^{1,2,3}$ STMIK GI MDP; J1. Rajawali No.14 Palembang, Telp(0711)376400 \\ Program Studi Sistem Informasi, STMIK GI MDP, Palembang \\ e-mail:1'herlina@mhs.mdp.ac.id, ${ }^{2}$ yohansenye@mhs.mdp.ac.id, ${ }^{3}$ fransiskaps@mdp.ac.id*
}

\begin{abstract}
Abstrak
Pabrik Roti ABC merupakan sebuah perusahaan yang bergerak pada produksi roti. Dalam menjalankan proses bisnisnya perusahaan sulit menentukan jumlah produksi, tidak mencatat omset penjualan, laporan pembelian bahan baku dan penjualan, dan tidak ada pencatatan terhadap penyebaran roti hasil produksi, Untuk itu diperlukan perancangan sistem infromasi manajemen rantai pasok yang akan memberikan pengendalian terhadap stok bahan baku dan hasil produksi serta menghasilkan laporan-laporan yang diperlukan perusahaan. Proses pengembangan menggunakan metode Rational Unified Process. Pada tahap permulaan untuk analisis permasalahan menggunakan PIECES, lalu untuk analisis kebutuhan menggunakan Usecase Diagram. Pada tahap perencanaan digunakan Class Diagram, Activity Diagram, dan Sequence Diagram. Pembangunan sistem menggunakan Php dan Mysql untuk basis datanya. Sistem informasi manajemen rantai pasok ini diharapkan dapat membantu dalam mengatasi permasalahan yang terjadi pada Pabrik Roti ABC dalam menjalankan kegiatan operasionalnya.
\end{abstract}

Kata kunci: Supply Chain Management, SCM, Weighted Moving Average, WMA, Pabrik Roti

\begin{abstract}
$A B C$ Bread Factory is a company engaged in the production of bread. In carrying out its business processes the company has difficulty in determining the production amount, does not record sales turnover, reports on purchases of raw materials and sales, and there is no recording of the distribution of bread produced, For this reason it is necessary to design a supply chain management information system that will provide control over the stock of raw materials and production results and produce reports needed by the company. The development process uses the Rational Unified Process method. In the initial stage for analysis of problems using PIECES, then for needs analysis using the Usecase Diagram. At the planning stage Class Diagrams, Activity Diagrams and Sequence Diagrams are used. Development of the system uses Php and Mysql for its database. The supply chain management information system is expected to be able to help in overcoming problems that occur in ABC Bakeries in carrying out its operational activities.
\end{abstract}

Keywords: Supply Chain Management, SCM, Weighted Moving Average, WMA, Bread Factory 


\section{PENDAHULUAN}

erkembangan dunia teknologi yang semakin berkembang di era globalisasi membawa $\mathrm{P}$ dampak yang besar pada berbagai aspek termasuk di dalam dunia bisnis. Persaingan bisnis dalam pasar global saat ini sangat dinamis dan sulit untuk diprediksi dengan berbagai perubahan kebutuhan dan keinginan konsumen. Dunia bisnis dalam pasar semakin luas dan bertebaran di mana-mana mengharuskan perusahaan untuk dapat mempunyai produk yang tepat pada waktu dan tempat yang tepat agar dapat unggul dalam pasar dan persaingan yang terjadi [1].

Setiap perusahaan pastinya ingin terus berkembang agar terus mendapatkan keuntungan. Perusahaan akan terus saling berlomba-lomba untuk memperoleh jumlah penjualan produk atau komoditas yang lebih besar yang mengindikasikan bahwa bisnis identik dengan persaingan dan pengetahuan serta informasi tentang sifat dan karakteristik dari para pesaing merupakan kunci untuk merumuskan persaingan yang akan terjadi kedepannya [2].

Ketatnya persaingan dalam dunia bisnis mengharuskan beberapa perusahaan untuk dapat terus mengembangkan bisnisnya seperti dalam penggunaan teknologi/ sistem informasi. Adanya bantuan teknologi/ sistem informasi tersebut dapat membantu perusahaan dalam mengembangkan serta menciptakan bisnis yang baru. Adanya teknologi/ sistem informasi tersebut dapat terjadi antara pemasok dengan konsumen yang dapat diterapkan pada manajemen rantai pasok atau supply chain management. Untuk dapat melanjutkan kelangsungan bisnis dan unggul dalam persaingan, rantai pasokan harus memahami kebutuhan dan tuntuan dari konsumen [1]. SCM yang baik dapat meningkatkan kemampuan bersaing bagi supply chain secara keseluruhan, tetapi tidak menyebabkan satu pihak berkorban dalam jangka Panjang [6].

Dalam pelaksanaannya, manajemen rantai pasok memiliki tujuan untuk memaksimalkan kemampuan perusahaan dalam persaingan serta memberikan keuntungan bagi perusahaan termasuk seluruh bagian sampai ke pelanggan akhir [3]. Manajemen rantai pasok merupakan penggabungan strategis dan sistematis antar perusahaan yang saling berkepentingan dalam memasok bahan baku, kemudian memproses atau memproduksi barang tersebut, lalu mendistribusikan barang tersebut sampai kepada konsumen akhir [1].

Manajemen rantai pasok tersebut kini juga terjadi pada industri makanan. SCM berbasis web merupakan sistem yang dapat menyatukan seluruh pelaku rantai pasok dalam sebuah sistem berbasis web yang terintegrasi [9]. Sistem yang terintegrasi bertujuan untuk mempermudah pihak - pihak yang terkait dalam proses distribusi produk [10]. Dengan adanya internet pihak pihak yang ada dalam jaringan SCM dapat membagi informasi dengan mudah dan cepat [7].

Pabrik Roti ABC merupakan sebuah perusahaan yang bergerak pada produksi roti. Proses bisnis yang hingga kini berjalan pada perusahaan tersebut adalah perusahaan terlebih dahulu memesan bahan baku pembuatan roti kepada supplier melalui telepon seluler lalu setelah supplier menerima pesanan tersebut, supplier mengecek stok bahan baku tersebut dan langsung mengirimkan kepada perusahaan. Apabila bahan baku yang dipesan telah sampai di tempat, perusahaan telebih dahulu melakukan pengecekan pada bahan baku roti untuk memastikan tidak ada barang yang cacat. Setelah itu perusahaan dapat langsung mengolah bahan baku tersebut menjadi roti. Apabila ada pelanggan yang ingin memesan roti yang diproduksi biasanya pelanggan memesan melalui telepon seluler dan langsung mengirimkan pesanan tersebut kepada pelanggan.

Permasalahan yang seringkali terjadi pada perusahaan adalah banyaknya produksi roti yang tidak sesuai dengan penjualan, sehingga banyak roti yang basi sebelum habis terjual, hal ini disebabkan karena pabrik terlebih dahulu memproduksi roti, setelah itu menunggu distributor untuk memesan roti. Selain itu juga perusahaan tidak dapat memastikan secara pasti dan tidak mencatat omset penjualan, laporan pembelian bahan baku dan penjualan roti setiap periodenya 
karena dalam penjualan roti kepada pelanggan, apabila roti yang sudah dijual kepada pelanggan sudah basi dalam jangka waktu kurang lebih satu minggu, maka roti tersebut akan dikembalikan lagi kepada Pabrik Roti $\mathrm{ABC}$ dan hal tersebut sudah termasuk hitungan rugi dari pihak perusahaan dari segi produksi maupun penjualannya. Penelitian ini bermaksud untuk membuat supply chain management pada Pabrik Roti ABC yang dapat mengatasi masalah yang terjadi.

\section{METODE PENELITIAN}

Penelitian ini dilakukan pada Pabrik Roti ABC yang merupakan perusahaan yang bergerak pada produksi roti. Penelitian ini terdiri dari 6 langkah seperti yang tergambar pada diagram alir penelitian yang dapat dilihat pada Gambar 1.

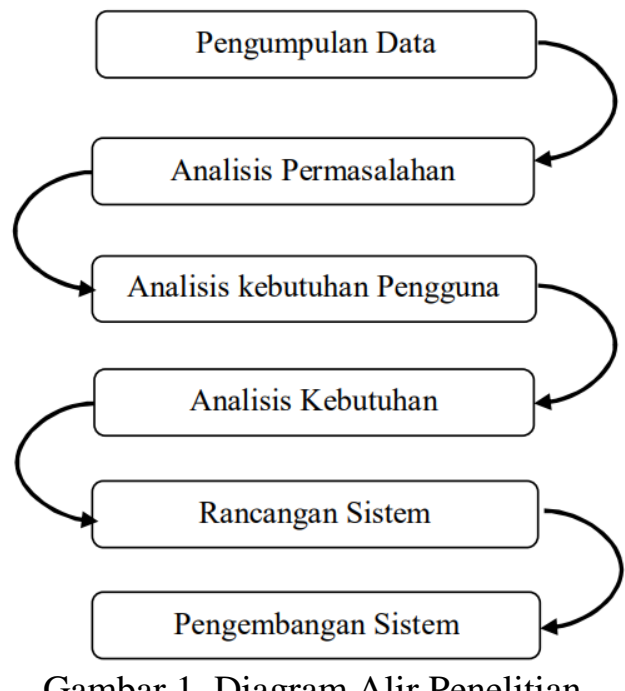

Gambar 1. Diagram Alir Penelitian

\subsection{Pengumpulan Data}

Pengumpulan data dilakukan dengan wawancara kepada pihak terkait di Pabrik Roti $\mathrm{ABC}$, observasi mengenai hal yang berhubungan dengan penjualan pada Pabrik Roti ABC, dan melakukan studi literatur pada penelitian yang terkait dengan sistem informasi manajemen rantai pasok.

\subsection{Analisis Permasalahan}

Analisis permasalahan pada Pabrik Roti ABC menggunakan kerangka PIECES yang terdiri dari Performance, Information. Economics, Control, Efficiency, dan Service, dapat dilihat pada Tabel 1.

Tabel 1. Analisis Permasalahan Kerangka PIECES

\begin{tabular}{|l|l|}
\hline \multicolumn{1}{|c|}{ PIECES } & \multicolumn{1}{c|}{ Permasalahan } \\
\hline Performance & Perusahaan lama dalam mencari nota-nota pembelian dan penjualan. \\
\hline Information & $\bullet \quad \begin{array}{l}\text { Perusahaan tidak dapat mengetahui rekapan penjualan per periode, omset } \\
\text { penjualan, dan persediaan bahan baku. }\end{array}$ \\
& $\begin{array}{l}\text { Tidak adanya informasi yang dapat membantu pabrik dalam merencanakan } \\
\text { produksi roti. }\end{array}$ \\
\hline Economics & Banyaknya roti yang kadaluarsa sebelum terjual. \\
\hline
\end{tabular}

Herlina, et.,al (Supply Chain Management Pabrik Roti ABC Dengan Metode Weighted Moving Average (WMA)) 


\begin{tabular}{|l|l|}
\hline Control & $\bullet \quad$ Perusahaan tidak dapat mengendalikan jumlah produksi roti. \\
& $\bullet \quad$ Nota-nota pembelian dan penjualan dapat rusak dan hilang. \\
\hline Efficiency & Pemborosan dalam penggunaan bahan baku. \\
\hline Service & Rendahnya kepuasan pemilik perusahaan dalam menjalankan bisnisnya. \\
\hline
\end{tabular}

\subsection{Analisis Kebutuhan}

Use case diagram adalah pemodelan awal yang menandakan sistem informasi akan dibangun. Use case mencirikan sebuah interaksi yang terjadi pada satu atau lebih aktor terhadap sistem informasi yang akan dibangun. Use case dibuat dengan tujuan untuk mengetahui fungsi apa saja yang terdapat dalam sistem informasi dan siapa saja yang berinteraksi dengan fungsi tersebut [4]. Use case diagram yang dirancang memiliki 5 (lima) aktor yaitu supplier, admin, bagian penjualan, distributor, dan pimpinan. Use case diagram dapat dilihat pada Gambar 2. 


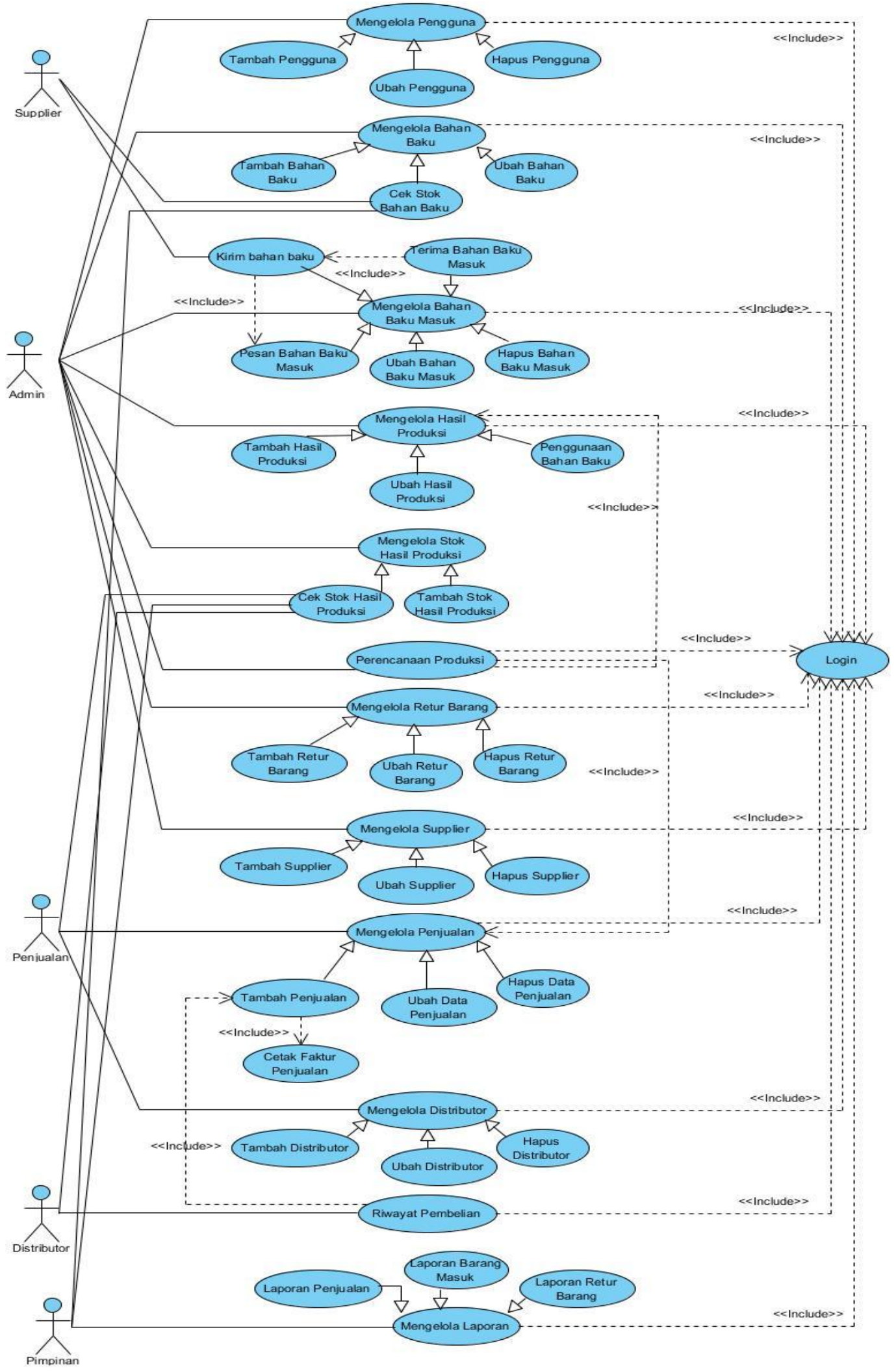

Gambar 2. Use Case Diagram

Herlina, et.,al (Supply Chain Management Pabrik Roti ABC Dengan Metode Weighted Moving Average (WMA)) 
Sedangkan hasil analisis kebutuhan pengguna dapat dilihat pada Tabel 2.

Tabel 2. Analisis Kebutuhan Pengguna

\begin{tabular}{|c|l|}
\hline Pengguna & \multicolumn{1}{|c|}{ Fungsi } \\
\hline Pimpinan & Pimpinan mempunyai hak untuk melihat detail laporan. \\
\hline Admin & $\begin{array}{l}\text { Admin mempunyai hak untuk melakukan pembelian bahan baku, mengolah } \\
\text { data master bahan baku, mengolah data master hasilproduksi, menambah stok } \\
\text { hasil produksi, menghitung perencanaan produksi, memproses retur barang. }\end{array}$ \\
\hline Supplier & $\begin{array}{l}\text { Supplier memiliki hak untuk memeriksa persediaan bahan baku, dan } \\
\text { menerima pesanan bahan baku dari pabrik. }\end{array}$ \\
\hline Distributor & $\begin{array}{l}\text { Distributor dapat memeriksa stok hasil produksi, dan dapat melihat riwayat } \\
\text { pembelian distributor masing - masing. }\end{array}$ \\
\hline Penjualan & $\begin{array}{l}\text { Penjualan memliki hak untuk memeriksa stok hasil produksi, melakukan } \\
\text { penjualan, dan mengolah data master distributor. }\end{array}$ \\
\hline
\end{tabular}

\subsection{Activity Diagram}

Rancangan sistem dibuat dengan menggunakan Unified Modeling Language (UML) yang merupakan bahasa standar yang dapat digunakan untuk menjelaskan dan memvisualisasikan artifak dari proses analisis dan desain berorientasi objek [8]. Diagram yang digunakan pada penelitian ini yaitu activity diagram, sequence diagram, dan class diagram. Activity diagram merupakan sebuah diagram yang menggambarkan aliran kerja dari aktivitas sebuah sistem yang berjalan pada perangkat lunak [4].

\subsubsection{Activity Diagram Terima Bahan Baku Masuk}

Activity Diagram ini menggambarkan urutan proses dari terima bahan baku masuk. Proses ini dimulai dari admin yang memilih data pesanan bahan baku yang berstatus dipesan, lalu admin klik tombol detail sistem menampilkan detail pesanan, selanjutnya admin klik terima, lalu sistem menampilkan pesan opsi, lalu admin memilih opsi OK. Dapat dilihat pada Gambar 3. 


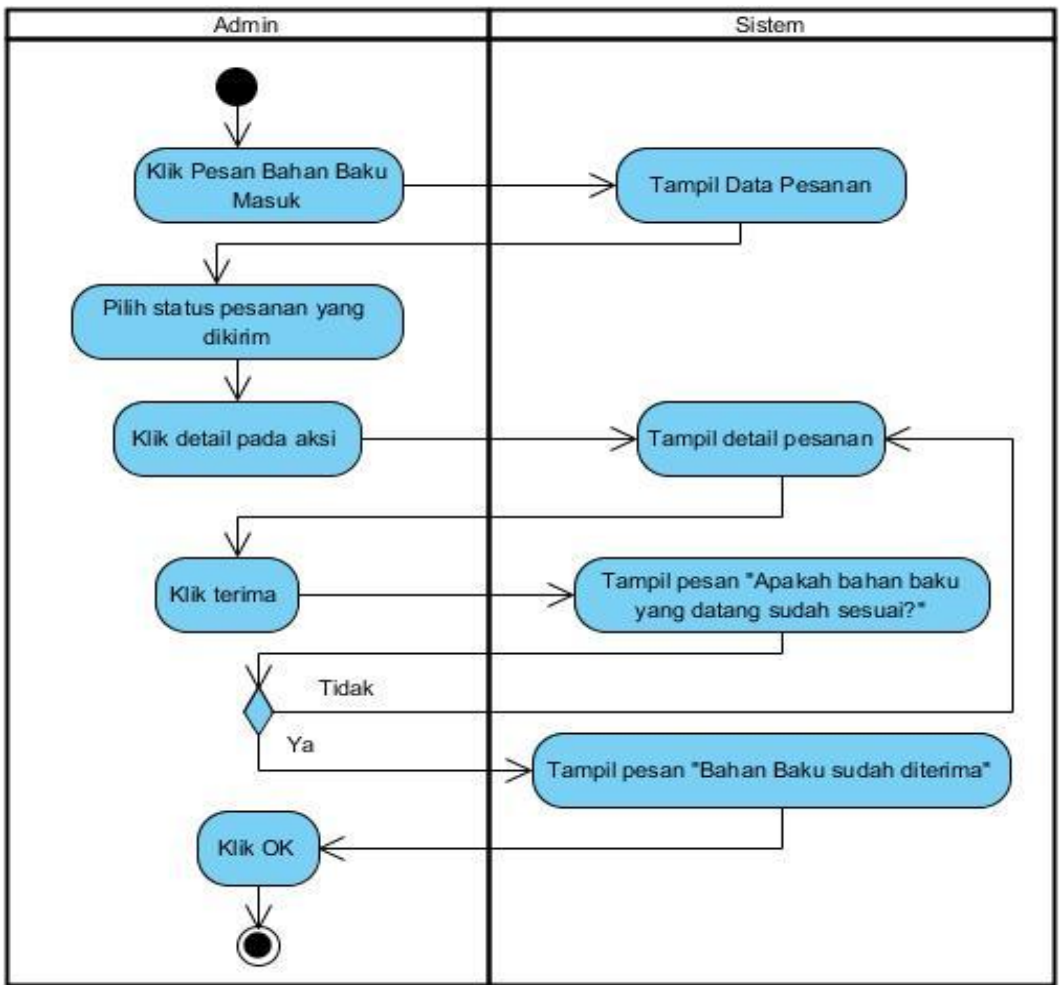

Gambar 3. Activity Diagram Terima Bahan Baku Masuk

\subsubsection{Activity Diagram Perencanaan Produksi}

Gambar 4 menggambarkan urutan proses dari perencanaan produksi, dimulai dari admin klik perencanaan produksi, lalu sistem menampilkan form perencanaan produksi, lalu admin memilih kode hasil produksi, selanjutnya admin mengklik tombol hitung, lalu sistem menampilkan hasil perhitungan.

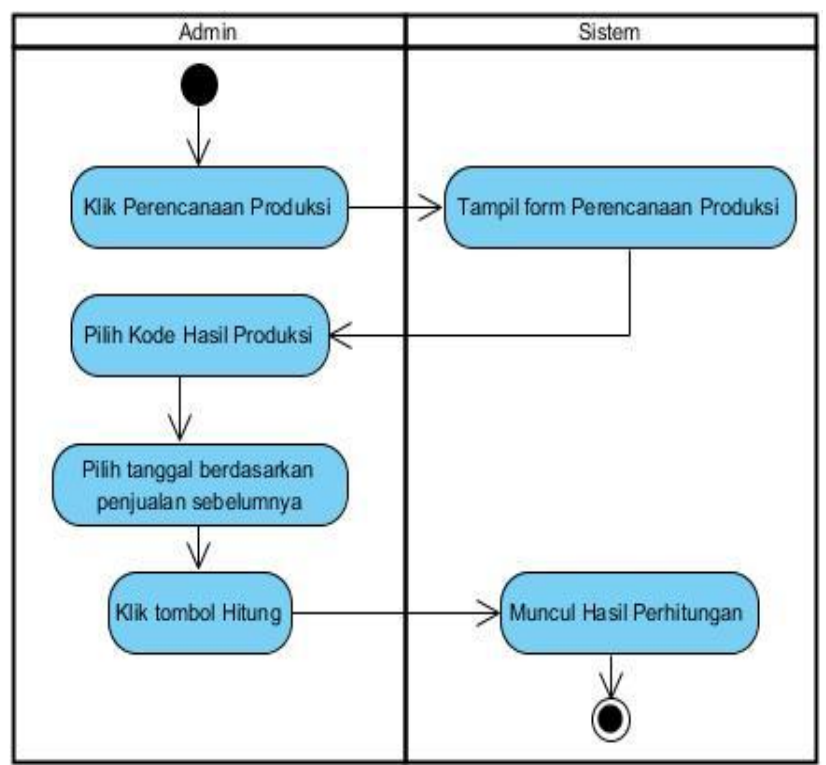

Gambar 4. Activity Diagram Perencanaan Produksi 


\subsection{Sequence Diagram}

Sequence diagram menggambarkan kelakuan objek pada use case dengan mendeskripsikan waktu hidup objek dan pesan yang dikirimkan dan diterima oleh tiap objek [4].

\subsubsection{Sequence Diagram Terima Bahan Baku Masuk}

Sequence Diagram Terima Bahan Baku Masuk ini menggambarkan waktu hidup objek, pesan yang disampaikan dan diterima objek pada saat admin melakukan penerimaan bahan baku yang telah sampai pada pabrik, dapat dilihat pada Gambar 5.

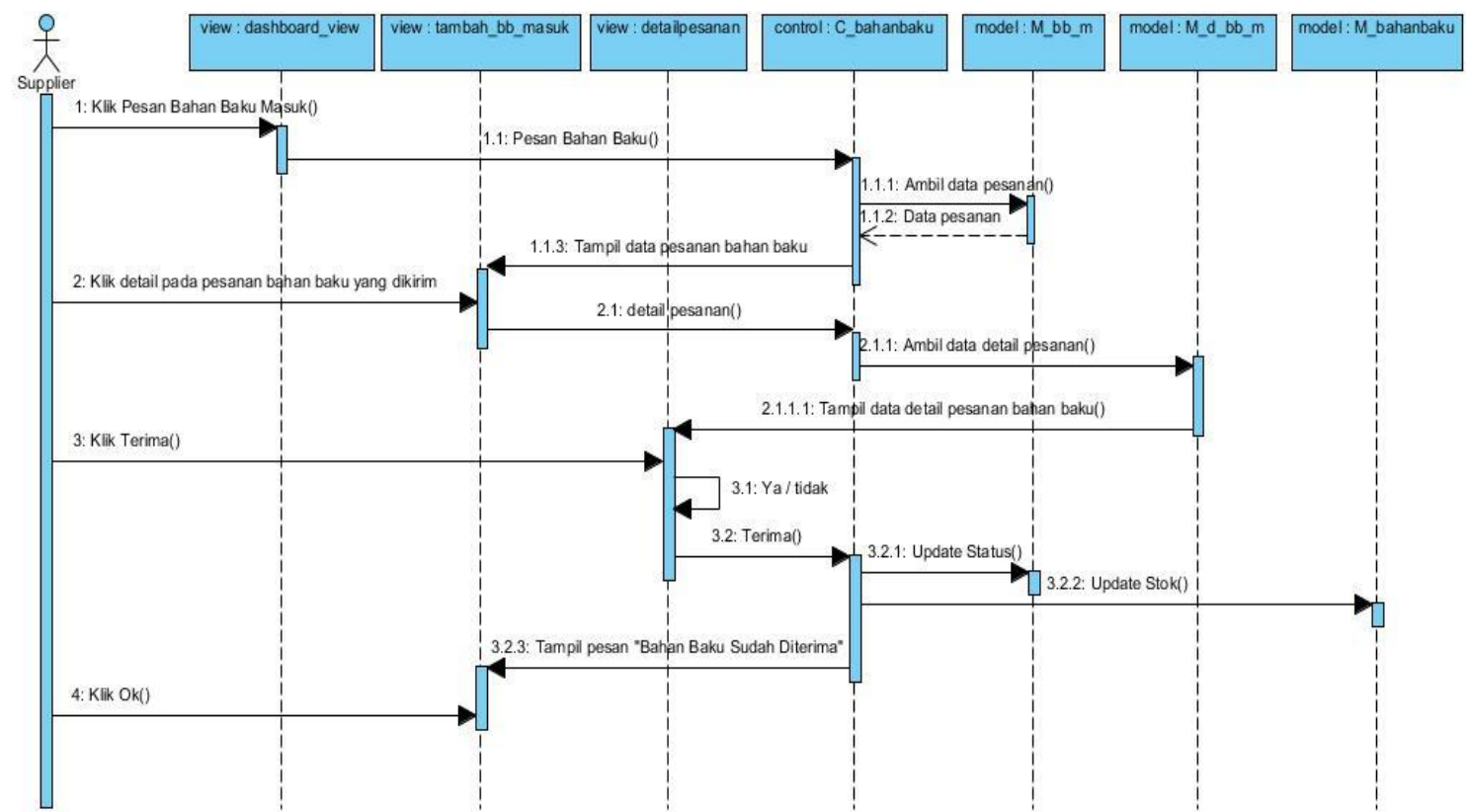

Gambar 5. Sequence Diagram Terima Bahan Baku Masuk

\subsubsection{Sequence Diagram Perencanaan Produksi}

Gambar 6 menggambarkan waktu hidup objek dan pesan yang disampaikan dan diterima antar objek pada saat bagian admin melakukan perhitungan pada perencanaan sebelum produksi roti dilakukan. 


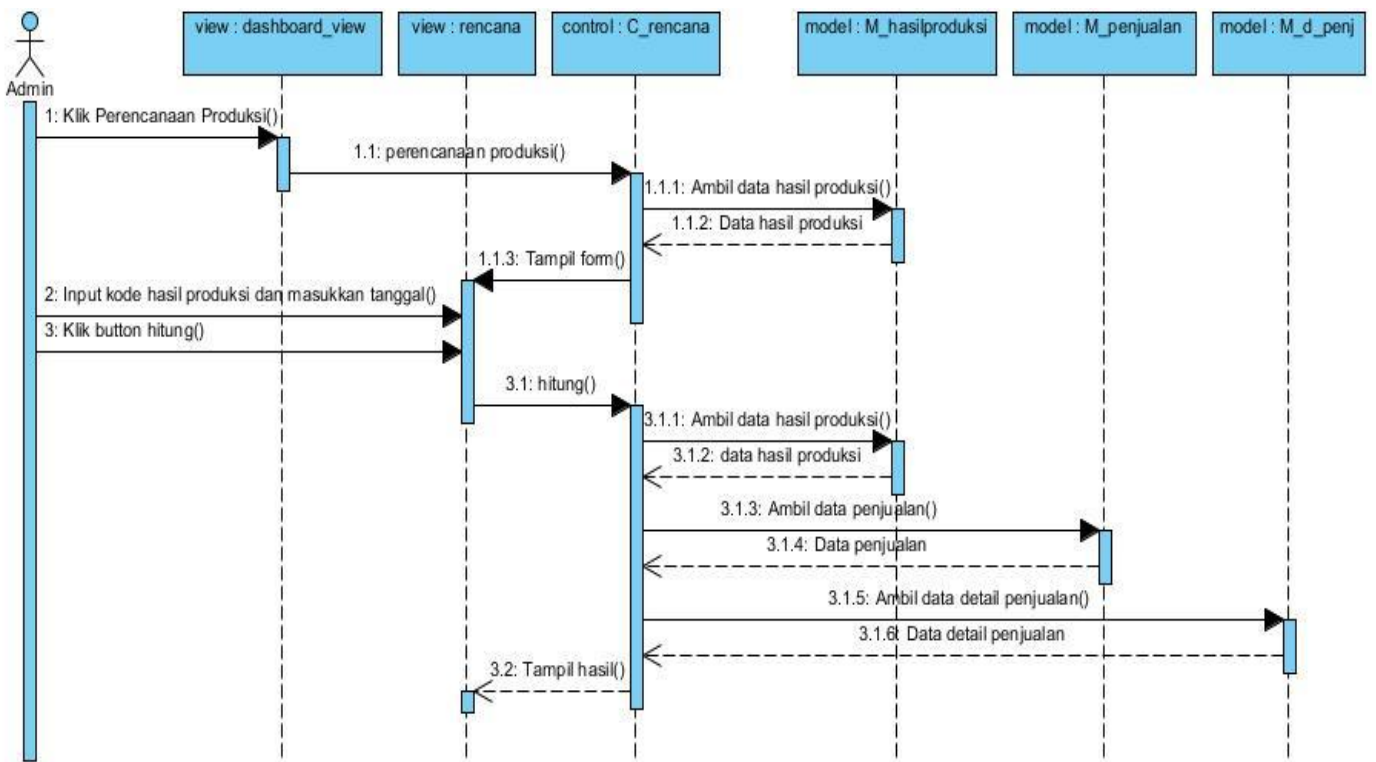

Gambar 6. Sequence Diagram Perencanaan Produksi

\subsection{Class Diagram}

Gambar 7 merupakan class diagram dari Sistem Manajemen Rantai Pasok pada Pabrik Roti ABC.

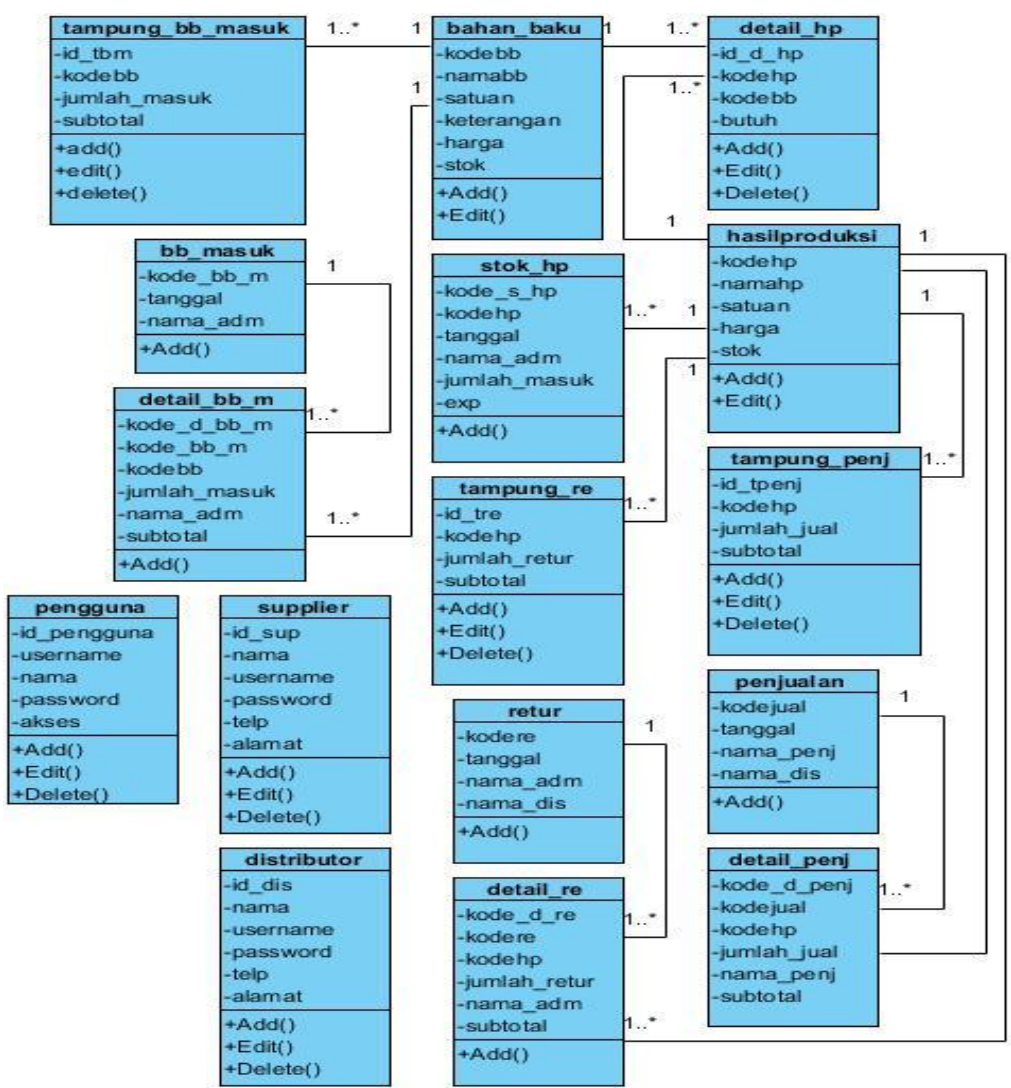

Gambar 7. Class Diagram

Herlina, et.,al (Supply Chain Management Pabrik Roti ABC Dengan Metode Weighted Moving Average (WMA)) 


\subsection{Pengembangan Sistem}

Setelah merancang sistem dengan Activity Diagram, Sequence Diagram, dan Class Diagram, maka tahap selanjutnya adalah melakukan pengembangan sistem atau pengkodean. Sistem ini dibuat menggunakan bahasa pemrograman $P H P$ serta $M y S Q L$ sebagai basis data.

\section{HASIL DAN PEMBAHASAN}

Pembahasan mengenai hasil dari penelitian sistem informasi manajemen rantai pasok pada Pabrik Roti ABC yang diperoleh disajikan dalam bentuk uraian teori secara kualitatif sebagai berikut.

\subsection{Perhitungan Weighted Moving Average (WMA)}

Perhitungan rata-rata bergerak dengan pembobotan menggunakan data sesungguhnya untuk mengasilkan perhitungan, pembobotan digunakan untuk menekan data yang paling baru. Tidak terdapat formula yang pasti dalam penentuan bobot [5]. perhitungan dengan menggunakan metode WMA, data yang diambil adalah data penjualan selama 7 (tujuh) hari terakhir dan nilai bobot maksimal yang telah ditentukan adalah 7 (tujuh) untuk data yang paling baru. Nilai bobot yang telah ditentukan pada tanggal pertama yaitu 1 (satu) lalu tanggal kedua memiliki bobot 2 (dua), begitu seterusnya sampai tanggal ketujuh yang berbobot 7 (tujuh). Nilai tersebut berdasarkan pendekatan dimana data yang paling baru bobotnya lebih besar. Berikut ini diambil data dari tanggal 16 Desember 2019 sampai 22 Desember 2019, untuk menghitung perencanaan banyak produksi roti kering pada tanggal 23 Desember 2019. Hasil perencanaan banyaknya produksi roti dapat dilihat pada Tabel 3.

Tabel 3. Perencanaan Banyak Produksi Untuk Roti Kering

\begin{tabular}{|c|c|c|}
\hline Tanggal & $\begin{array}{c}\text { Penjualan } \\
\text { Aktual }\end{array}$ & $\begin{array}{c}\text { Perencanaan Banyak Produksi Dengan } \\
\text { Pergerakan Rata-Rata 7 hari }\end{array}$ \\
\hline 16 Desember 2019 & 30 & - \\
\hline 17 Desember 2019 & 25 & - \\
\hline 18 Desember 2019 & 26 & - \\
\hline 19 Desember 2019 & 22 & - \\
\hline 20 Desember 2019 & 27 & - \\
\hline 21 Desember 2019 & 28 & - \\
\hline 22 Desember 2019 & 15 & - \\
\hline 23 Desember 2019 & 19 & 23,35 \\
\hline
\end{tabular}

Berikut rumus yang digunakan untuk menghitung rencana banyak produksi.

$$
W M A=\frac{\sum((\text { Bobot_untuk_periode_n }) \cdot \text { Per min taan_dalam_periode_n } n)}{\sum \text { Bobot }}
$$

Untuk mendapatkan perencanaan banyak produksi pada tanggal 23 Desember 2019 dihitung dengan cara menjumlahkan bobot yang dikali dengan jumlah penjualan perhari, lalu hasil penjumlahan tersebut dibagi dengan total bobot yaitu 28 yang didapat dari $7+6+5+4+3+2+1=28$. Berikut contoh perhitungannya. 
$\frac{[(7 \times 15)+(6 \times 28)+(5 \times 27)+(4 \times 22)+(3 \times 26)+(2 \times 25)+(1 \times 30)]}{28}=23,35$.

Maka setelah dilakukan perhitungan didapatlah hasil perencanaan produksi roti kering yaitu 23,35 ikat.

Source code untuk perhitungan WMA, dapat dilihat pada Gambar 8 dan 9.

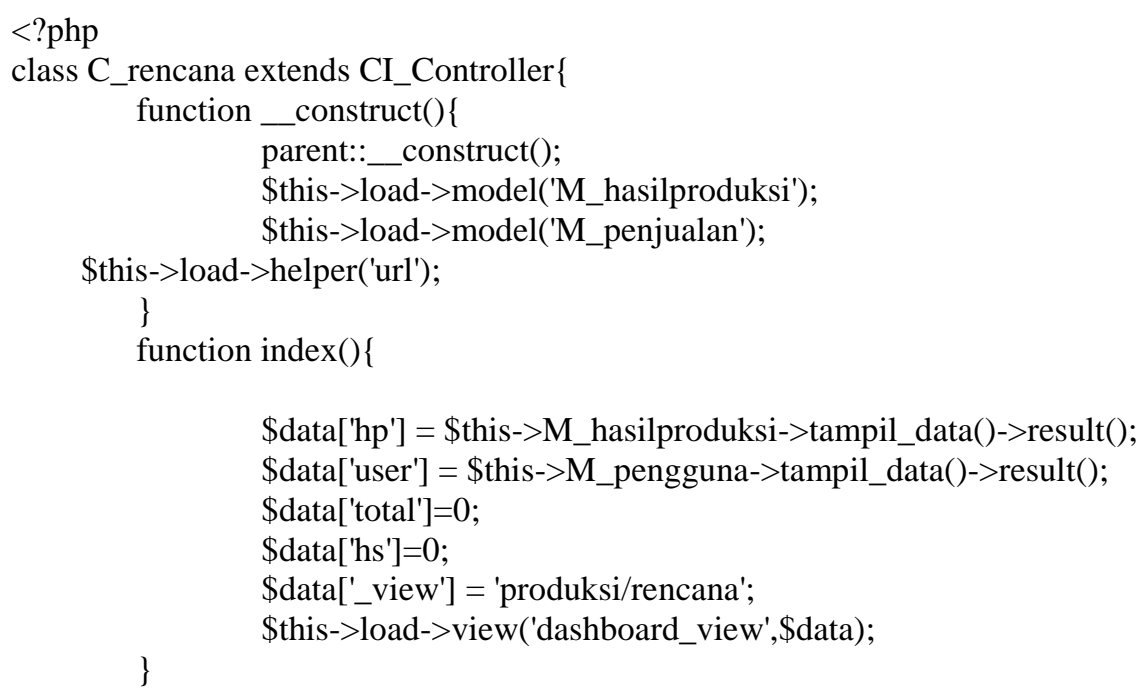

function hitung ()\{

\$data['hp'] = \$this->M_hasilproduksi->tampil_data()->result();

\$data['jual'] = \$this->M_penjualan->tampil_data()->result () ;

\$data['tgl1'] = \$this->db->query("select sum(detail_penj.jumlah_jual) as jumlah,(sum(detail_penj.jumlah_jual)*1) as hasil from detail_penj inner join penjualan on detail_penj.kodejual=penjualan.kodejual where tanggal='\$_POST[tanggal1]' and detail_penj.kodehp='\$_POST[kodehp]'")->row_array(0);

\$h1 = \$this->db->query("select sum(detail_penj.jumlah_jual) as jumlah,(sum(detail_penj.jumlah_jual)*1) as hasil from detail_penj inner join penjualan on detail_penj.kodejual=penjualan.kodejual where tanggal='\$_POST[tanggal1]' and detail_penj.kodehp='\$_POST[kodehp]'")->row_array(0);

\$data['tg12'] = \$this->db->query("select sum(detail_penj.jumlah_jual) as jumlah,(sum(detail_penj.jumlah_jual)*2) as hasil from detail_penj inner join penjualan on detail_penj.kodejual=penjualan.kodejual where tanggal='\$_POST[tanggal2]' and detail_penj.kodehp='\$_POST[kodehp]'")->row_array(0);

$\$$ h2 $=$ \$this->db->query("select sum(detail_penj.jumlah_jual) as jumlah,(sum(detail_penj.jumlah_jual)*2) as hasil from detail_penj inner join penjualan on detail_penj.kodejual=penjualan.kodejual where tanggal='\$_POST[tanggal2]' and detail_penj.kodehp='\$_POST[kodehp]'")->row_array(0);

\$data['tgl3'] = \$this->db->query("select sum(detail_penj.jumlah_jual) as jumlah,(sum(detail_penj.jumlah_jual)*3) as hasil from detail_penj inner join penjualan on detail_penj.kodejual=penjualan.kodejual where tanggal='\$_POST[tanggal3]' and detail_penj.kodehp='\$_POST[kodehp]'")->row_array(0);

Gambar 8. Source Code WMA (1) 
\$h3 = \$this->db->query("select sum(detail_penj.jumlah_jual) as jumlah,(sum(detail_penj.jumlah_jual)*3) as hasil from detail_penj inner join penjualan on detail_penj.kodejual=penjualan.kodejual where tanggal='\$_POST[tanggal3]' and detail_penj.kodehp='\$_POST[kodehp]'")->row_array(0);

\$data['tgl4'] = \$this->db->query("select sum(detail_penj.jumlah_jual) as jumlah,(sum(detail_penj.jumlah_jual)*4) as hasil from detail_penj inner join penjualan on detail_penj.kodejual=penjualan.kodejual where tanggal='\$_POST[tanggal4]' and detail_penj.kodehp='\$_POST[kodehp]"')->row_array(0);

\$h4= \$this->db->query("select sum(detail_penj.jumlah_jual) as jumlah,(sum(detail_penj.jumlah_jual)*4) as hasil from detail_penj inner join penjualan on detail_penj.kodejual=penjualan.kodejual where tanggal='\$_POST[tanggal4]' and detail_penj.kodehp='\$_POST[kodehp]'")->row_array(0);

\$data['tgl5'] = \$this->db->query("select sum(detail_penj.jumlah_jual) as jumlah,(sum(detail_penj.jumlah_jual)*5) as hasil from detail_penj inner join penjualan on detail_penj.kodejual=penjualan.kodejual where tanggal='\$_POST[tanggal5]' and detail_penj.kodehp='\$_POST[kodehp]'")->row_array(0);

\$data['tgl6'] = \$this->db->query("select sum(detail_penj.jumlah_jual) as jumlah,(sum(detail_penj.jumlah_jual)*6) as hasil from detail_penj inner join penjualan on detail_penj.kodejual=penjualan.kodejual where tanggal='\$_POST[tanggal6]' and detail_penj.kodehp='\$_POST[kodehp]'")->row_array(0);

\$h6 $=$ \$this->db->query("select sum(detail_penj.jumlah_jual) as jumlah,(sum(detail_penj.jumlah_jual)*6) as hasil from detail_penj inner join penjualan on detail_penj.kodejual=penjualan.kodejual where tanggal='\$_POST[tanggal6]' and detail_penj.kodehp='\$_POST[kodehp]'")->row_array(0);

\$data['tgl7'] = \$this->db->query("select sum(detail_penj.jumlah_jual) as jumlah,(sum(detail_penj.jumlah_jual)*7) as hasil from detail_penj inner join penjualan on detail_penj.kodejual=penjualan.kodejual where tanggal='\$_POST[tanggal7]' and detail_penj.kodehp='\$_POST[kodehp]'")->row_array(0);

$\$$ h7 = \$this->db->query("select sum(detail_penj.jumlah_jual) as jumlah,(sum(detail_penj.jumlah_jual)*7) as hasil from detail_penj inner join penjualan on detail_penj.kodejual=penjualan.kodejual where tanggal='\$_POST[tanggal7]' and detail_penj.kodehp='\$_POST[kodehp]'")->row_array(0);

\$data['total']=\$h1['jumlah']+\$h2['jumlah']+\$h3['jumlah']+\$h4['jumlah']+\$h5['jumlah']+\$h6['ju mlah']+\$h7['jumlah'];

\$hasil2=(\$h1['hasil']+\$h2['hasil']+\$h3['hasil']+\$h4['hasil']+\$h5['hasil']+\$h6['hasil']+\$h7['hasil']

)$/ 28$

\$data['hs']=number_format(\$hasil2,2);

\$data['_view'] = 'produksi/rencana';

\}

\$this->load->view('dashboard_view',\$data);

\}

Gambar 9. Source Code WMA (2) 


\subsection{Tampilan Antarmuka Perencanaan Produksi}

Gambar 10 merupakan tampilan antarmuka dari fungsi perencanaan produksi. Halaman ini hanya bisa diakses oleh bagian admin dan digunakan untuk menghitung banyak produksi. Pada tampilan ini berisikan form untuk menhitung banyak produksi. Admin terlebih dahulu memilih kode hasil produksi, lalu klik di tombol hitung, maka tampil data penjualan dari 7 (tujuh) hari yang lalu dan hasil perhitungan yang merupakan banyak produksi.

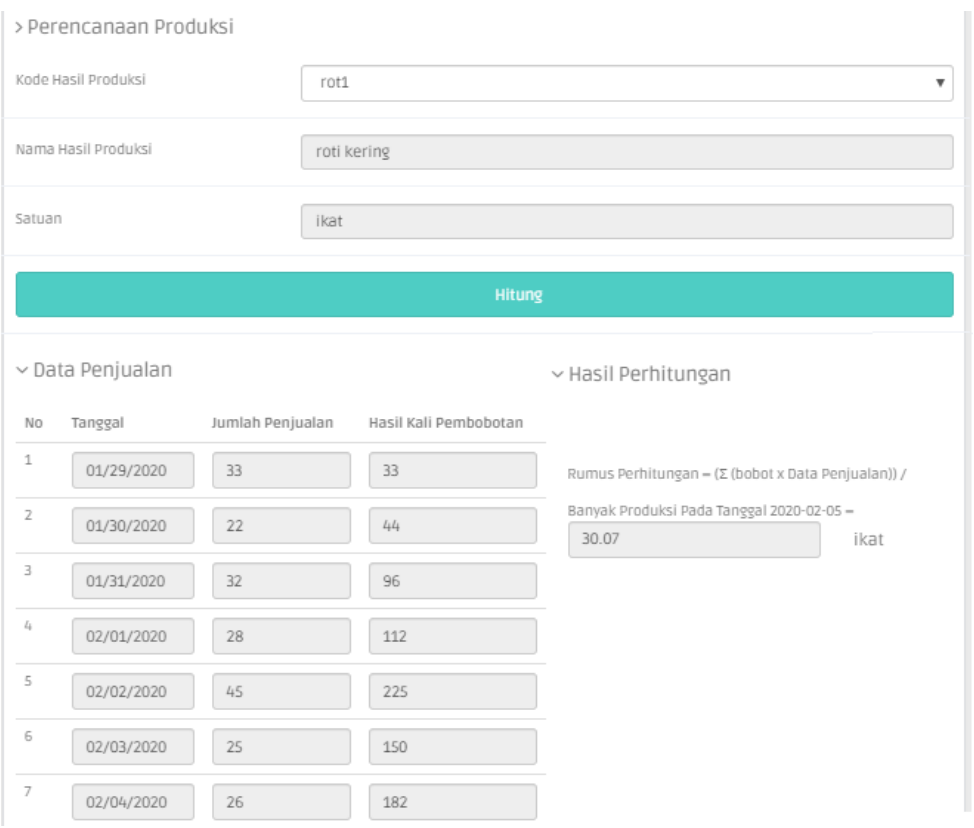

Gambar 10. Form Perencanaan Produksi

\subsection{Tampilan Antarmuka Laporan Barang Masuk}

Gambar 11 merupakan tampilan antarmuka laporan barang masuk. Halaman ini hanya bisa diakses oleh pimpinan, halaman ini menampilkan barang masuk pada periode tertentu.

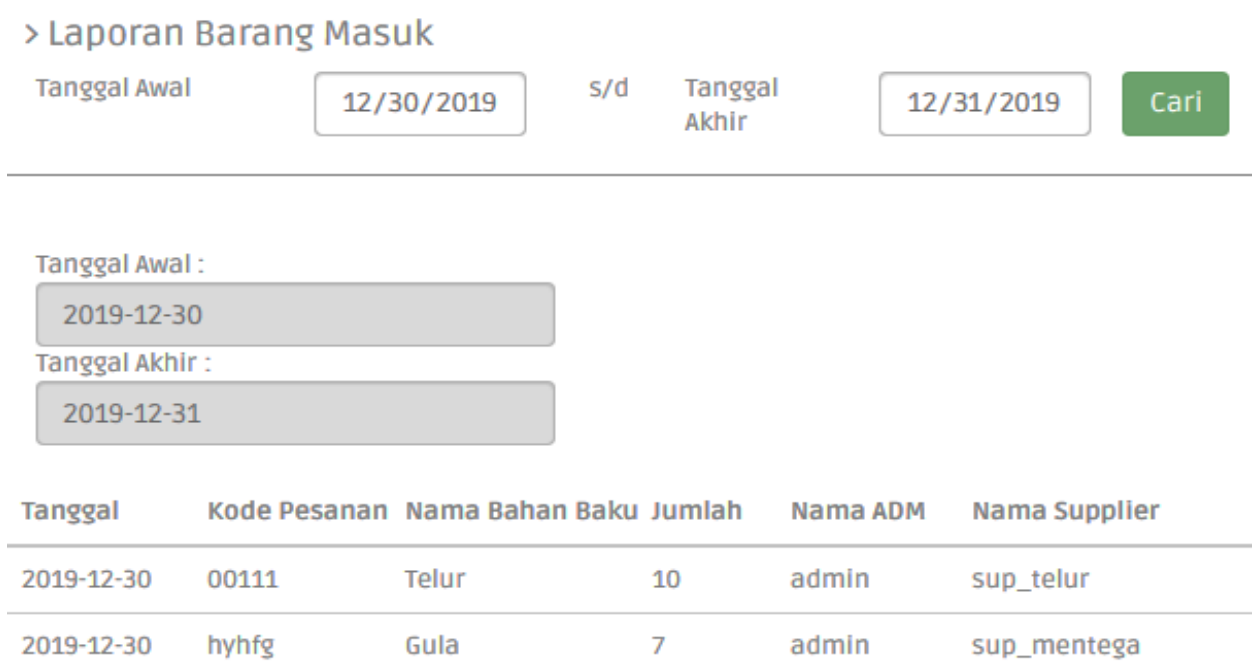

Gambar 11. Laporan Barang Masuk 


\subsection{Tampilan Antarmuka Laporan Penjualan}

Gambar 12 merupakan tampilan antarmuka laporan penjualan. Halaman ini hanya bisa diakses oleh pimpinan, halaman ini menampilkan penjualan pada periode tertentu.

\begin{tabular}{|c|c|c|c|c|c|c|}
\hline \multicolumn{2}{|c|}{ Tanggal Awal } & $01 / 01 / 2020$ & \multicolumn{2}{|c|}{ s/d Tanggal Akhir } & $01 / 03 / 2020$ & Cari \\
\hline \multicolumn{7}{|c|}{ Tanggal Awal : } \\
\hline \multicolumn{4}{|c|}{ 2020-01-01 } & & & \\
\hline \multicolumn{4}{|c|}{ Tanggal Akhir : } & & & \\
\hline \multicolumn{4}{|c|}{$2020-01-03$} & & & \\
\hline Tanggal & Kode Jual & Nama Hasil Produksi & Jumlah & Nama Penjual & Nama Distributor & Subtotal \\
\hline 2020-01-01 & p014 & roti coklat & 11 & penjualan & Rudi & 11000 \\
\hline 2020-01-01 & p014 & roti tawar & 45 & penjualan & Rudi & 270000 \\
\hline 2020-01-02 & p015 & roti coklat & 14 & penjualan & Rudi & 14000 \\
\hline 2020-01-02 & p015 & roti manis & 33 & penjualan & Rudi & 82500 \\
\hline 2020-01-02 & p015 & roti tawar & 12 & penjualan & Rudi & 72000 \\
\hline 2020-01-03 & p016 & roti coklat & 15 & penjualan & Rudi & 15000 \\
\hline 2020-01-03 & p016 & roti manis & 12 & penjualan & Rudi & 30000 \\
\hline 2020-01-03 & p016 & roti tawar & 33 & penjualan & Rudi & 198000 \\
\hline
\end{tabular}

Gambar 12. Laporan Penjualan

\subsection{Tampilan Antarmuka Laporan Retur}

Gambar 13 merupakan tampilan antarmuka laporan retur. Halaman ini hanya bisa diakses oleh pimpinan, halaman ini menampilkan retur pada periode tertentu.

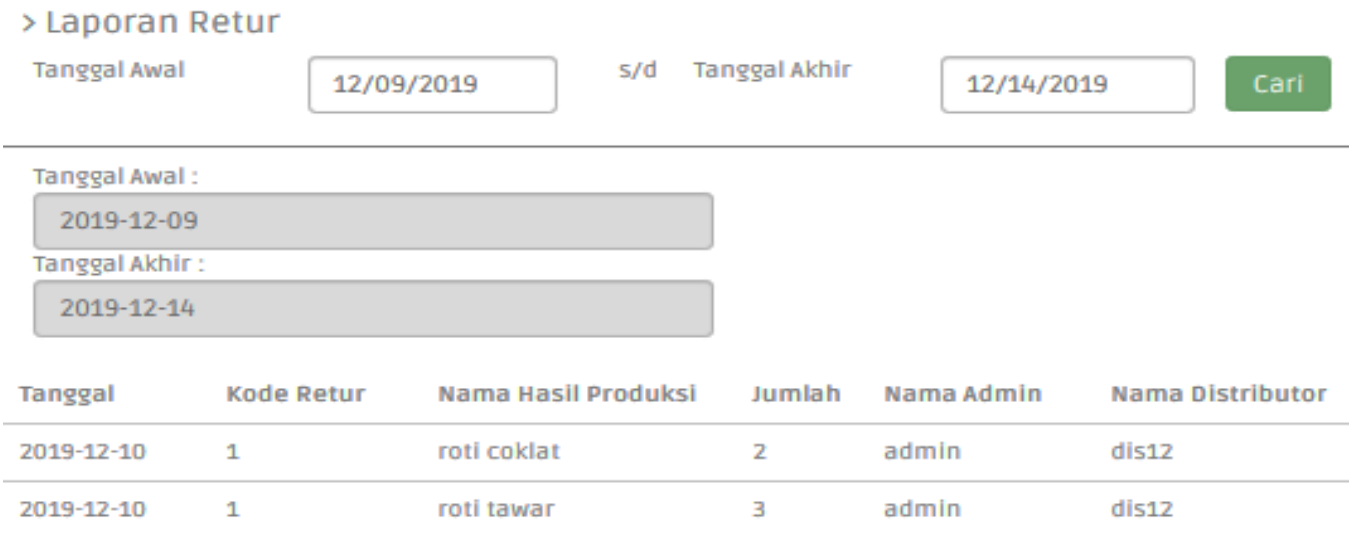

Gambar 13. Laporan Retur 


\section{KESIMPULAN DAN SARAN}

Berdasarkan hasil pengembangan dan analisis yang telah penulis lakukan, maka dapat ditarik kesimpulan bahwa sistem informasi manajemen rantai pasok dapat membantu perusahaan dalam merencanakan banyak produksi dengan lebih baik dan cepat, lalu memudahkan perusahaan dalam mengefisiensikan ketersediaan bahan baku dan hasil produksi, serta dapat meningkatkan manajemen perusahaan dengan memproses laporan bahan baku, penjualan, dan retur.

Dalam perancangan dan pengembangan sistem ini, penulis sadar bahwa masih terdapat kekurangan pada sistem yang dibangun. Maka, penulis memberikan beberapa saran yaitu, sebelum menggunakan website ini, terlebih dahulu diberikan petunjuk dan pelatihan cara penggunaan kepada pengguna, sehingga website dapat digunakan dengan maksimal. Lalu diharapkan kedepannya sistem informasi manajemen rantai pasok ini dapat ditambahkan fitur backup secara otomatis, serta diharapkan kedepannya dalam sistem ini, penerapan metode Weighted Moving Average lebih dikembangkan untuk pengambilan dalam data penjualan pada hari - hari tertentu, seperti hari libur dan hari raya.

\section{DAFTAR PUSTAKA}

[1] Anatan, L. 2008. Supply Chain Management: Teori dan Aplikasi. Alfabeta. Jakarta.

[2] Rangkuti, F. 2010. Penelitian dan Analisa Pemasaran. Gramedia. Jakarta.

[3] Tunggal, AW. 2008. Supply Chain Management. Harvarindo. Jakarta.

[4] Rosa, AS., dan Shalahudin. 2013. Rekayasa Perangkat Lunak. Informatika. Bandung.

[5] Heizer, J., dan Render, B. 2015. Manajemen Operasi. Salemba Empat. Jakarta.

[6] Nurmaidah, M., Pudjiantoro TH., dan Renaldi, F. Pembangunan Sistem Manajemen Rantai Pasok dalam Proses Produksi Teh di PT Perkebunan Nusantara III. Jurnal Pasti, XI 1,22-31.

[7] Andita., Jaya, TI. 2016. Rancang Bangun Sistem Informasi Manajemen Rantai Pasokan di PT Argo Pantes. Jurnal Teknik Informatika, 9, 2.

[8] R. A. Permana. 2015. UML (Unified Modeling Language). Academia. Tangerang.

[9] R. A. Nggili dan R. Ronald. 2017. "Supply Chains Management (SCM) Batu Mulia Khas Nusantara di Kotamadya Salatiga,” No. 2, 169-186.

[10] Rivai, F., dan Sutopo, J. 2018. Sistem Informasi Supply Chain Management Pakan Ternak Sapi. Universitas Teknologi Yogyakarta.

Herlina, et.,al (Supply Chain Management Pabrik Roti ABC Dengan Metode Weighted Moving Average (WMA)) 